\title{
Article
}

Mycosphere

Doi 10.5943/mycosphere/8/8/15

Copyright (C) Guizhou Academy of Agricultural Sciences

\section{Natural products of Nothophoma multilocularis sp. nov. an endophyte of the medicinal plant Rhazya stricta}

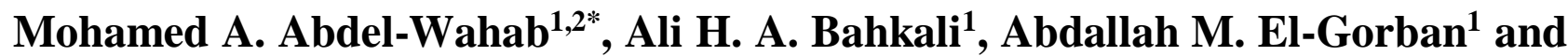 \\ Mohamed S. Hodhod ${ }^{1}$
}

${ }^{1}$ Department of Botany and Microbiology, College of Science, King Saud University, P.O. Box: 2455, Riyadh 1145, Saudi Arabia.

${ }^{2}$ Department of Botany and Microbiology, Faculty of Science, Sohag University, Sohag 82524, Egypt.

Abdel-Wahab FA, Bahkai AHA, El-Gorban AM, Hodhod MS. 2017 - Natural products of Nothophoma multilocularis sp. nov. an endophyte of the medicinal plant Rhazya stricta. Mycosphere 8(8), 1185-1200. Doi 10.5943/mycosphere/8/8/15

\begin{abstract}
In the present study, we isolated endophytic fungi from the medicinal plant Rhazya stricta from Saudi Arabia. Twenty-eight fungal isolates representing five species were isolated from 21 leaves (10 young and 11 old) of $R$. stricta. These fungi include two species of Alternaria, Aspergillus sp., Nothophoma sp. and one species producing sterile mycelia. Based on morphology and phylogenetic analyses of LSU rDNA, we describe Nothophoma (E-2-5) as a new species to science. Nothophoma multilocularis is characterized by its large multiloculate pycnidia and its larger conidial dimensions than the six described Nothophoma species. A table (Table 3) comparing the morphology and the host of the seven Nothophoma species is provided, along with a key for their identification. The culture filtrates of the isolated endophytic fungi were extracted using ethyl acetate and were tested against pathogenic microbes. Fifty-five bioactive chemical compounds were identified from the crude extracts of Nothophoma multilocularis using GC-MS. Ten major bioactive compounds were recorded namely: Di-n-octyl phthalate representing $53.98 \%$ of the crude extract, 2-Allyl-3,4dimethox ybenzaldehyde (10.26\%), Maltol (9.45\%), Cetene (2.73\%), 1-Tetradecene (2.07\%), E-15Heptadecenal (2.06 \%), 2,5-Cyclohexadien-1-one $(1.88 \%), \quad 1-O c t a d e c e n e ~(1.36 \%)$, Diethyldithiophosphinic acid $(1.17 \%)$ and Phenol, 2,4-di-t-butyl-6-nitrophenol (1.07 \%). These compounds showed strong antimicrobial activity in combination.
\end{abstract}

Key words - Antibacterial - antifungal - Didymellaceae - molecular phylogeny

\section{Introduction}

Rhazya stricta Decne is a native, perennial, poisonous, evergreen dwarf shrub plant in India and the Middle East including Saudi Arabia (Täckholm 1974, Boulos 1995). Rhazya stricta is an important traditional medicinal species used to cure various diseases in South Asia and the Middle East. Leaf extracts from $R$. stricta have been used in folkloric medicine for the treatment of fever, sore throat, rheumatism, diabetes, inflammatory conditions and syphilis (El-Ghonemy 1993, Adam 1998). Rhazya stricta is a member of Apocynaceae that includes about 1300 species in 300 genera and most of which have medicinal and economic values (Täckholm 1974, Boulos 1995). Leaf extracts contain alkaloids, glycosides, flavonoids, tannins and triterpenes (Baeshen et al. 2014, 
2015). Some of its alkaloids have also been reported to have anticancerous properties (Gilani et al. 2007). Over 100 alkaloids have been isolated, characterized and identified from $R$. stricta leaves (e.g. Andersen et al. 1987, Atta-ur-Rahman \& Khanum 1985, 1987), stems (Atta-ur-Rahman et al. 1996), roots (Atta-ur-Rahman et al. 1996) and legumes (Atta-ur-Rahman \& Malik 1985, 1987), as well as from mixtures of aerial parts (Sultana et al. 2005). Seeds of $R$. stricta are a good source of unsaturated oil which can be used as a feedstock for biodiesel production (Nehdi et al. 2014).

It has been postulated in many studies that the internal fungi or endophytes may be responsible in producing some of the secondary metabolites found in plants ( $\mathrm{Li}$ et al. 2005, Nisa et al. 2015). Endophytes are ecological group; most of them belong to Ascomycota and live inside healthy living tissues of every plant on earth (Guo et al. 2001, Wang et al. 2005, Hyde \& Soytong 2008). Fungi are also well-known for their ability to produce medicinal compounds (De Silva et al. 2013, Degenkolb \& Vilcinskas 2016). Thus, there have been several studies that have explored the production of novel compounds from endophytes of medicinal plants (Garcia et al. 2012, Nalini et al. 2014, Nath et al. 2015, Liu et al. 2016, Khan et al. 2017). A single study on the endophytic fungi of $R$. stricta has been carried out in Oman (Khan et al. 2015) and they identified two new enzyme inhibitory compounds: sorokiniol and radicinol and two known cyclic peptides (Khan et al. 2015, Ali et al. 2016). The aims of this study were therefore to identify endophytic fungi of Rhazya stricta, as well as to determine active secondary metabolites in the extracts of the isolated endophytic fungi. We focused on the antibacterial and antifungal properties of these extracts.

\section{Materials \& Methods}

\section{Collection of plant materials and isolation of endophytic fungi}

Fresh healthy-looking leaves of Rhazya stricta were collected from Rawdat Khoraim, $25^{\circ} 13^{\prime}$ $49^{\prime \prime}$ N, 47 10' 15" E, located 90 Km north east of Riyadh, Saudi Arabia. Samples were collected on 7 May 2015 and kept in clean plastic bags, in ice bags, returned to the laboratory and processed within 24 hours (Verma et al. 2007). In the laboratory, plant samples were washed with running tap water. The leaves were cut into segments (about $0.5 \mathrm{~cm}$ long). Segments were surface-sterilized by submersion in $95 \%$ ethanol for 1 minute, $2.5 \%$ sodium hypochlorite for 3 minutes, and $95 \%$ ethanol for 1 minute and completed by rinsing in sterile water three times ( 1 minute each). In each Petridish ( $9 \mathrm{~cm}$ in diameter), a total of four surface sterilized segments were evenly placed onto the surface of PDA plates supplemented with chloramephenicol for suppressing bacterial growth. The dishes were incubated at $28 \mathrm{C}$ and hyphal tips growing out from the surface sterilized plant pieces were transferred to new PDA plates and preserved in cryotubes in $10 \%$ glycerol at $-80 \mathrm{C}$ in a deep freezer (Verma et al. 2007, Kharwar et al. 2008).

\section{Morphological identification of endophytic fungi}

Pure isolates were classified into morphotypes (sensu Lacap et al. 2003) according to the shape and color of the colonies. Fruiting morphotypes were identified based on their fruiting structures.

\section{Molecular identification of Nothophoma multilocularis}

Pure culture of the fungus was grown in YMG broth $(4 \mathrm{~g}$ yeast extract, $10 \mathrm{~g}$ glucose, $10 \mathrm{~g}$ malt extract in 1 liter sea water) until sufficient mycelia was formed for DNA extraction. Total genomic DNA was extracted using Microbial DNA extraction kit (MOBIO; Mo Bio Laboratories, Carlsbad, CA, USA) according to the manufacturer's instructions. LROR and LR7 primers were used for the amplification of partial LSU ribosomal DNA (Vilgalys \& Hester 1990). Sequencing was made by Macrogen Inc., Korea. Details of the methods used are described in Abdel-Wahab et al. (2016). Sequences were assembled using Sequencher 4.2.2 (Gene Codes Corporation). Closest sequences were obtained using blast searches at GenBank. Sequences were aligned using ClustalX (Thompson et al. 1997) and manual adjustments of the sequences were carried out when necessary. Representatives of Pleosporaceae were used as out group (Fig. 1). Phylogenetic analyses were carried out using PAUP* v. 4.0 b10 (Swofford 2002). Maximum-likelihood analysis (Felsenstein 
1981) was performed using heuristic searches with the random stepwise addition of 100 replicates and tree bisection-reconnection (TBR) rearrangements. The optimal model of nucleotide substitution for the ML analyses was determined using hierarchical likelihood ratio tests as implemented in Modeltest 3.7 (Posada \& Crandall 1998). The model selected as the best fit for LSU rDNA dataset was TrNef+I+G. Maximum-parsimony (MP) trees were obtained by 100 random addition heuristic search replicates using phylogenetic packages, and 1000 bootstrap replicates were performed employing 5 random addition heuristic searches. Bayesian analyses were performed by using PAUP v. 4.0b10 (Swofford 2002) and MrBayes 3.1.2 (Huelsenbeck \& Ronquist 2001, Ronquist \& Huelsenbeck 2003). The model of evolution (SYM+I+G) was estimated by using MrModeltest 2.2 (Nylander 2004). Posterior probabilities (PP) were performed by Markov Chain Monte Carlo sampling (BMCMC). Five million generations were run in four chains with sampling every 100 generations, yielding 50000 trees, of which the first 12500 trees, representing the burn-in phase of the analyses, were discarded and the remaining trees used for calculating posterior probabilities (PP) in the majority rule consensus tree. Produced phylogenetic analyses were visualized using Njplot (Perrière \& Gouy 1996). The alignment was deposited in TreeBASE (http://www.treebase.org) under the submission S21238.

\section{Cultivation and extraction and natural product isolation}

Fungal isolates were grown on PDA plates for two weeks. Mycelia with agar were cut into small cubes $(\mathrm{ca} 1 \mathrm{~mm})$. Cubes were transferred aseptically to one Liter flask that contains $600 \mathrm{ml}$ of YMG broth (10 gm yeast extract, $4 \mathrm{gm}$ malt extract and $10 \mathrm{gm}$ glucose in 1 liter of distilled water) and adjust $\mathrm{pH}$ at 5.5. The seeded flask was incubated at $28 \mathrm{C}$ under stationary conditions until the concentrations of the glucose level reach $0.05 \%$. The cultures were harvested and filtered through Whatman filter paper by vacuum filtration using pump and Büchner funnel. Filtrates were extracted using ethyl acetate in one to one ratio and then dried by rotary evaporator to give the crude extracts. Weights of the crude extracts were determined and were dissolved in dimethyl sulfoxide (DMSO) to give concentration $20 \mathrm{mg} / \mathrm{ml}$.

\section{Test organisms}

The pathogenic bacteria Escherichia coli (gram negative), Staphylococcus aureus (gram positive) and the yeast species, Candida albicans and the filamentous fungus Aspergillus fumigatus were used to carry out the bio-assay.

\section{Antimicrobial activity}

For antimicrobial evaluation, disk diffusion bioassay was performed. Plates of bacterial and fungal spore suspension were prepared using pour plate method. Five $\mu l$ was added of the prepared DMSO solutions to each disk so that each disk has $100 \mu \mathrm{g}$ of the crude extract. Plates were incubated at $37^{\circ} \mathrm{C}$ for bacteria and at $28^{\circ} \mathrm{C}$ for fungi and clear zone were measured in $\mathrm{mm}$.

\section{Isolation of metabolites}

The crude extract of Nothophoma multilocularis gave the best results and was selected for further study and was grown on $10 \mathrm{~L}$ of the same medium structure under the same growth conditions. The resulted crude extracts were fractionated using silica gel columns. The weight of the crude extract was determined and 30 to 50 -fold of that weight of silica gel was used. Crude extract was dissolved in one $\mathrm{ml}$ of acetone and mixed with one gram of silica and mixed and stirred until crude extract is totally mixed with silica gel and acetone is evaporated. Ethyl acetate is used as the solvent. Fractions were collected every 5 minutes. A total of 15 fractions were collected. Similar fractions were determined using TLC sheets and mixed. Bioassays of the fractions were carried out as described above. Active fractions were further fractioned using TLC sheets. Compounds in the active subfractions were determined using mass spectrometry (GC-MS).

\section{Results \& Discussion}

Twenty-eight fungal isolates representing five species were isolated from 21 leaves (10 young and 11 old) of Rhazya stricta. These fungi include two species of Alternaria, Aspergillus sp., 
Nothophoma sp. and one sterile mycelia (Table 1). Khan et al. (2015) cultured five endophytic fungal isolates from $500 \mathrm{stem}$, root and leaf segments of Rhazya stricta from Oman. These five isolates represent three fungi namely: Alternaria sp., Bipolaris sorokiniana Shoemaker and Phoma sp. Their results are in harmony with our results in terms of low fungal diversity and Alternaria species were common to both studies. Compared with other studies in terrestrial ecosystems, the numbers of endophytes is very low (five taxa in this study, 35 from Livistona chinensis in Guo et al. (2000), 28 OTUs from Bletilla ochracea using molecular techniques in Tao et al. (2008).

The isolated fungi were tested against pathogenic microbes. Three species gave positive results, of which Alternaria sp. 1 (E-2-1) gave positive results against Gram positive (Staphylococcus aureus) and Gram negative bacteria (Escherichia coli). Aspergillus sp. (E-2-2) showed antimicrobial activity against bacteria and Candida albicans. Nothophoma multilocularis (E-2-5) gave best results against bacteria and fungi and was chosen for further study (Table 2).

Table 1 Endophytic fungi isolated from 21 leave segments of Rhazya stricta

\begin{tabular}{|c|c|c|c|c|}
\hline Taxon & & & $\mathbf{N}$ & $\%$ \\
\hline Alternaria sp.1 (E-2-1) & & & 7 & 33.3 \\
\hline Alternaria sp. 2 (E-2-3) & & & 3 & 14.3 \\
\hline Aspergillus sp. (E-2-2) & & & 5 & 23.8 \\
\hline Nothophoma multilocularis (E-2-5) & & & 7 & 33.3 \\
\hline Sterile mycelium (E-2-4) & & & 6 & 28.6 \\
\hline \multicolumn{5}{|l|}{$\begin{array}{l}\text { N number of isolates. } \\
\text { \% Frequency of occurrence. }\end{array}$} \\
\hline \multicolumn{5}{|c|}{$\begin{array}{l}\text { Table 2: Bioassay results of the isolated fungi (the numbers are the clear zones in } \\
\text { centimeter) }\end{array}$} \\
\hline $\begin{array}{c}\text { Taxon } \\
\end{array}$ & $\begin{array}{l}\text { Staphylococcus } \\
\text { aureus }\end{array}$ & $\begin{array}{l}\text { Escherichia } \\
\text { coli }\end{array}$ & $\begin{array}{l}\text { Candida } \\
\text { albicans }\end{array}$ & $\begin{array}{c}\text { Aspergillus } \\
\text { fumigatus }\end{array}$ \\
\hline Alternaria sp.1 (E-2-1) & 0.8 & 1 & negative & negative \\
\hline Alternaria sp. 2 (E-2-2) & negative & negative & negative & negative \\
\hline Aspergillus sp. (E-2-3) & 0.9 & 1 & 1 & negative \\
\hline Nothophoma multilocularis (E-2-5) & 1.7 & 1.5 & negative & 1 \\
\hline Sterile mycelium (E-2-4) & negative & negative & negative & negative \\
\hline
\end{tabular}

\section{Nothophoma dataset:}

The LSU rDNA dataset consisted of 13 taxa of which seven are the Nothophoma and three belong to Pleosporaceae and used as the outgroup. The dataset includes 826 characters with 44 parsimony-informative characters. One most parsimonious tree was obtained after the search, all with a tree length of 79 steps, a consistency index of 0.7722 , a retention index of 0.856 and a rescaled consistency index of 0.661. Maximum likelihood analysis produced one tree $(-\ln$ likelihood $=$ 1570.98604). Bayesian analyses produced two phylogenetic trees of which one is shown in Fig. 1. MP and ML produced trees with similar topology to the one shown in Fig. 1. The new Nothophoma species nested within the clade containing the six other known species of Nothophoma with high statistical support 94/98/100 for MP/ML/Bayesian pp respectively. Nothophoma multilocularis clustered with $N$. gossypiicola and $N$. macrospora with weak to moderate bootstrap support 75/53 for $\mathrm{P} / \mathrm{ML}$ respectively. Morphological characteristics and phylogenetic analyses of LSU rDNA sequences show that Nothophoma multilocularis (E-2-5) represent unknown fungus and it is described here as a new species. Similar phylogenetic tree topology and bootstrap support based on ITS and $\beta$ tubulin (TUB 2) of Nothophoma species was recently published (Bai et al. 2016). 
MycoBank number: MB821831; Facesoffungi number: FoF03436

Etymology - named for its multiloculate pycnidia.

Holotype - AUMC-12003-H.

Hyphae 2.5-6 $\mu \mathrm{m}$ thick, hyaline to yellow-brown, septate, immersed in the media. Pycnidia 175$1500 \mu \mathrm{m}$ diameter, globose, subglobose or irregular in shape, stromatic, unilocule to multilocular or confluent with one to several long necks (up to 6), ostiolate, coriaceous to carbonaceous, black, superficial on or immersed into the agar. Necks 250-400 $\mu \mathrm{m}$ long, 80-130 $\mu \mathrm{m}$ wide, black, cylindrical with wide base. Pycnidial wall 38-80 $\mu \mathrm{m}$ thick forming textura angularis, one-layered,

8-18 cell layers, consists of polygonal cells with wide lumina 6-10 $\mu \mathrm{m}$, dark-brown to black to outside and hyaline to inside; pycnidial centrum filled with pseudoparenchymatous cells that disintegrate with the development of the conidia. Conidiogenous cells 11-17 $\times 9-18 \mu \mathrm{m}$, phialidic, flask-shaped or polygonal, hyaline to yellow-brown. Conidia 9-20 $\times 3-4(5) \mu \mathrm{m}(x=14.9 \times 3.9 \mu \mathrm{m}, \mathrm{n}=50)$, unicellular, hyaline, smooth, cylindrical or clavate with rounded ends, with a few minutes polar guttules, conidium length/width ratio are 4-5.5/1 $(x=3.84, \mathrm{n}=50)$. Chlamydospores $10-16 \mu \mathrm{m}$ in diam., globose, subglobose to polygonal, brown to dark-brown, in chains or in large masses of cells $65-130 \times 22-45 \mu \mathrm{m}$. NaOH spot test: negative.

Culture characteristics - Colonies on Oatmeal Agar (OA), covering 40-45 mm diameter after 7 days in the dark at $25 \mathrm{C}$; circular with complete edge, olive brown, the first $0.5 \mathrm{~cm}$ to the margin is hyaline in color, heavily sporulating with fertile stromatic pycnidia, flat, slimy growth; reverse olive brown. Colonies on PDA, covering 28-30 mm diam. In Petri-dishes after 7 days in the dark at $25 \mathrm{C}$; circular with complete edge, olivaceous-brown, heavily sporulating with fertile stromatic pycnidia, flat, slimy growth; reverse olive brown. Colonies on CMA, covering 32-35 mm diam. after 7 days in the dark at $25 \mathrm{C}$; circular with complete edge, light-brown, poor sporulation, flat; reverse light-brown.

Material examined - SAUDI ARABIA, Riyadh City, Rawadat Khoraim (25 $13^{\prime} 49^{\prime \prime} \mathrm{N}, 47^{\circ} 10^{\prime}$ $15^{\prime \prime} \mathrm{E}$ ), an endophyte of the healthy-looking leaves of the medicinal plant Rhazya stricta, 7 May 2015, Mohamed S. Hodhod (AUMC-12003-H, holotype), ex-type living cultures AUMC-12003.

Notes - Nothophoma Q. Chen \& L. Cai, typified by N. infossa (Ellis \& Everh.) Q. Chen \& L. Cai. was recently established to accommodate five Phoma species clustered in a monophyletic clade in Didymellaceae (Chen et al. 2015), Sordariomycetes (Maharachchimbura et al. 2016). Another Nothophoma species, N. macrospora Valenzuela-Lopez, Stchigel, Cano \& Deanna A. Sutton, was described from a human clinical specimen (Crous et al. 2016). The first report of Nothophoma quercina (Syd. \& P. Syd.) Q. Chen \& L. Cai on Ulmus was provided by Tibpromma et al. (2017). Phylogenetic analyses based on LSU rDNA placed the new species along with the six species of Nothophoma with high statistical support 94/98/100 for MP/ML/Bayesian pp respectively. Nothophoma multilocularis clustered with $N$. gossypiicola and N. macrospora (Fig. 1). The three species produce conidia over $10 \mu \mathrm{m}$ in length (Table 3). Nothophoma multilocularis differs from $N$. gossypiicola by its large pycnidia $(175-1500 \mu \mathrm{m}$ vs. $100-250 \mu \mathrm{m}$ diam), the number of necks (up to 6 vs $0-1)$, larger conidiogenous cells $(11-17 \times 9-18 \mu \mathrm{m}$ vs. $5-8 \times 5-8 \mu \mathrm{m})$ and conidia $(9-20$ $\times 3-4(5) \mu \mathrm{m}$ vs. $10-12.5 \times 2.5-3.5 \mu \mathrm{m})$. Nothophoma gossypiicola is a well-known cause of leaf spots and stem cankers on cotton, Gossypium spp. (De Gruyter 2002). Nothophoma multilocularis differs from $N$. macrospora by its large pycnidia (175-1500 $\mu \mathrm{m}$ vs. 100-300 $\mu \mathrm{m}$ diam.), wider pycnidial wall $(38-80 \mu \mathrm{m}$ vs. $15-25 \mu \mathrm{m})$ and conidia $(9-20 \times 3-4(5) \mu \mathrm{m}$ vs. $10-15 \times$

2.5-3.5 $\mu \mathrm{m})$. Conidia in N. multilocularis are unicellular, while in N. macrospora they are 0-2 septate.

\section{Natural products of Nothophoma multilocularis:}

Fifty-five bioactive chemical compounds were identified from the crude extracts of Nothophoma multilocularis using GC-MS. Ten major bioactive compounds were recorded namely: Di-n-octyl phthalate representing $53.98 \%$ of the crude extract, 2-Allyl-3,4-dimethoxybenzaldehye, (10.26\%), Maltol (9.45 \%), Cetene (2.73\%), 1-Tetradecene (2.07\%), E-15-Heptadecenal (2.06 \%), 2,5Cyclohexadien-1-one (1.88\%), 1-Octadecene (1.36\%), Diethyldithiophosphinic acid (1.17\%) and Phenol, 2,4-di-t-butyl-6-nitrophenol (1.07 \%). 


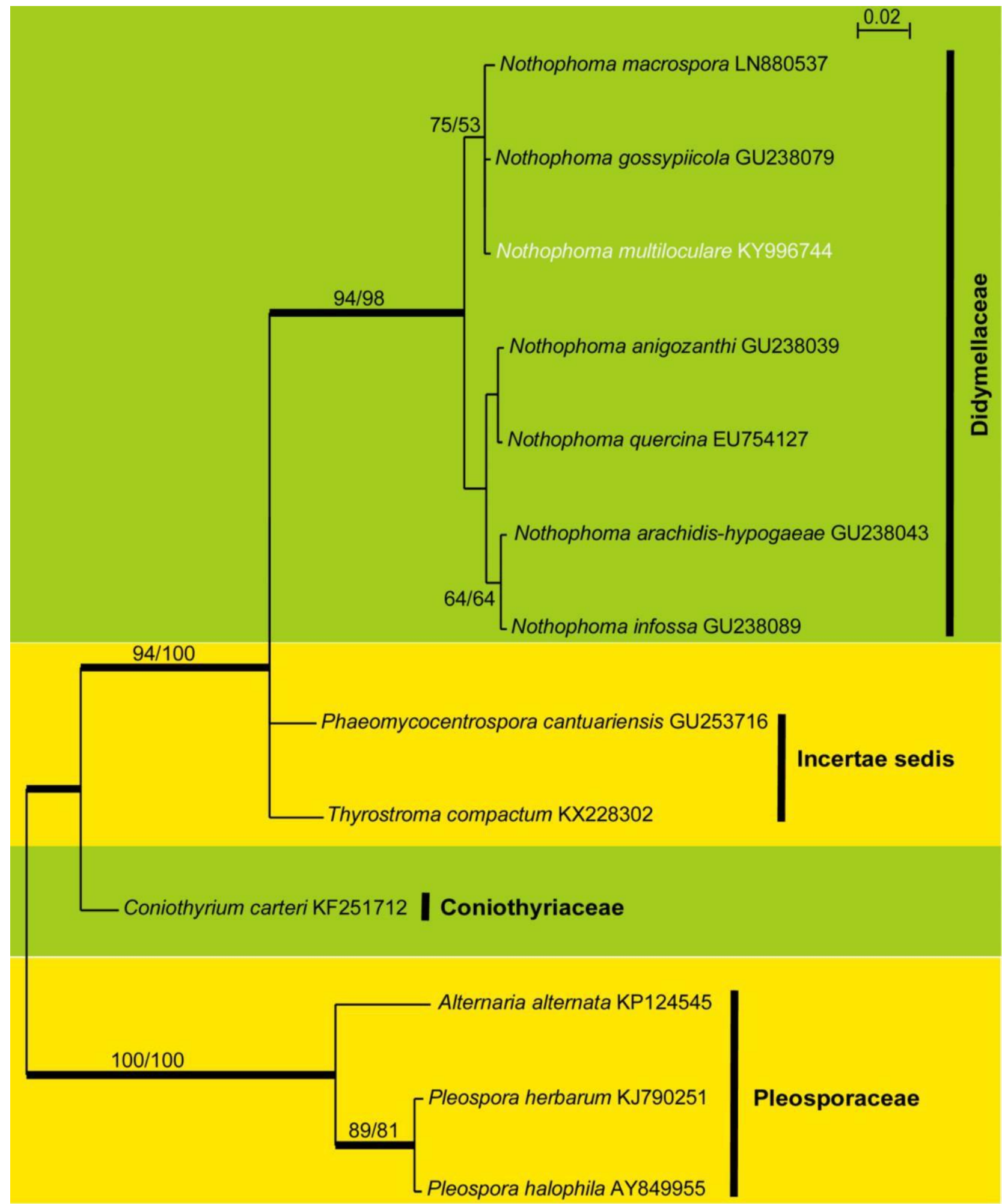

Fig. 1 - Phylogenetic relationships of the new species with other Nothophoma species. Phylogenetic tree derived from Bayesian analysis, based on the nucleotide sequences of LSU rDNA. The numbers on the nodes indicate pp values $\geq 95 \%$ (in bold), MP bootstrap and MP bootstrap values $\geq$ $50 \%$. The tree is rooted to representatives of Pleosporaceae. New species is in white. 


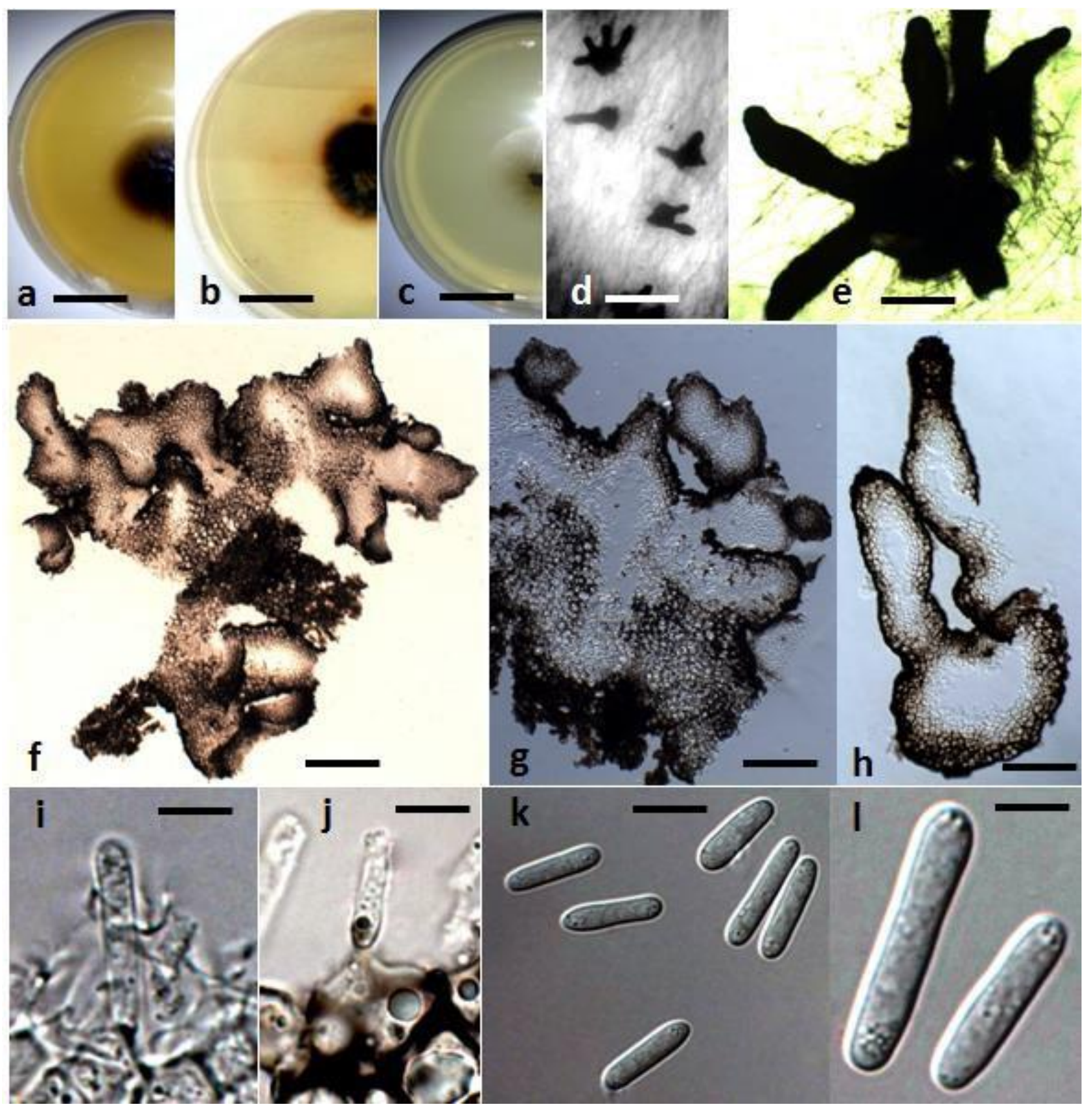

Fig. 2 - Nothophoma multilocularis from the culture (ex-type). a-c Cultures from above incubated for 6 days on: a OA, b PDA, c CMA. d, e Pycnidia. f-h Vertical sections through stromatic pycnidia. $\mathbf{i}, \mathbf{j}$ Conidiogenous cells and young conidia. $\mathbf{k}, \mathbf{l}$ Conidia. Scale bars: $\mathbf{a}-\mathrm{c}=2 \mathrm{~cm}, \mathrm{~d}=1000$ $\mu \mathrm{m}, \mathrm{e}, \mathrm{f}=200 \mu \mathrm{m}, \mathrm{g}, \mathrm{h}=100 \mu \mathrm{m}, \mathrm{i}-\mathrm{k}=10 \mu \mathrm{m}, \mathrm{l}=5 \mu \mathrm{m}$.

These compounds showed strong antimicrobial activity in combination. Di-n-octyl phthalate was the major compound in the active fraction representing $53.98 \%$ (Table 4). Phthalates are used in the manufacture of a variety of plastics and coating products. Phthalates were recorded from various biological resources including plants (Duc et al. 2007). Fatty foods such as milk, butter, and meats are found to be the main sources of natural bis(2-ethylhexyl) phthalate and other phthalates (Kohn et al. 2000). 1, 2-Benzenedicarboxylic acid bis (2-ethylhexyl) phthalate has been isolated from a marine alga, Sargassum weightii, from the seeds of Ricinus. 


\begin{tabular}{|c|c|c|c|c|c|c|}
\hline Species & Conidiomata & Conidiogenous cells & Conidia & Chlamydospores & $\begin{array}{l}\text { Culture } \\
\text { characteristics }\end{array}$ & Host \\
\hline N. anigozanthi ${ }^{l}$ & $\begin{array}{l}\text { Pycnidial, solitary or aggregated, } \\
\text { olivaceous buff } 70-130 \mu \mathrm{m} \text { diam, turn } \\
\text { black with age, } 155-280 \times 140-230 \\
\mu \mathrm{m} \text {. Ostioles } 1-4(-6) \text { on long neck. } \\
\text { Wall 3-6-layered } 16-41 \mu \mathrm{m} \text { thick., }\end{array}$ & $\begin{array}{l}\text { Phialidic, hyaline, } \\
\text { ampulliform to } \\
\text { doliiform, } 5-9 \times 4.5-7.5 \\
\mu \mathrm{m} \text {. }\end{array}$ & $\begin{array}{l}\text { Ellipsoidal, aseptate, } \\
3.5-5 \times 1.5-2.5 \mu \mathrm{m}, \\
\text { with several minute } \\
\text { guttules. }\end{array}$ & Absent & $\begin{array}{l}\text { On OA } 40-50 \mathrm{~mm} \text {, after } \\
7 \text { d, olivaceous, reverse } \\
\text { concolourous. } \mathrm{NaOH} \\
\text { spot test: a luteous } \\
\text { discoloration on } \mathrm{MEA} \text {, } \\
\text { change to dull green. }\end{array}$ & $\begin{array}{l}\text { Parasitic on } \\
\text { Anigozanthus } \\
\text { spp. }\end{array}$ \\
\hline $\begin{array}{l}\text { N. } \text { arachidis- }^{-} \\
\text {hypogaeae }^{2}\end{array}$ & $\begin{array}{l}\text { Pycnidial } 80-200 \mu \mathrm{m} \text { in diam, globose } \\
\text { to bottle-shaped, solitary or in raws, } \\
\text { not confluent, papillate, citrine-honey } \\
\text { then olivaceous to black. Wall made } \\
\text { up of 3-5 layers, outer layers } \\
\text { pigmented. }\end{array}$ & $\begin{array}{l}\text { Globose to bottle- } \\
\text { shaped, 3-8 } \times 3-7 \mu \mathrm{m} \text {. }\end{array}$ & $\begin{array}{l}\text { Oblong to } \\
\text { ellipsoidal without } \\
\text { or with two minute } \\
\text { polar guttules, } \\
\text { aseptate, } 3.2-5.2 \times \\
1.8-2.4 \mu \mathrm{m} \text {. }\end{array}$ & Absent & $\begin{array}{l}\text { On OA } 47-48 \mathrm{~mm} \text {, grey } \\
\text { olivaceous reverse } \\
\text { olivaceous. NaOH spot } \\
\text { test: on MA a slight } \\
\text { reddish discoloring } \\
\text { occurs. }\end{array}$ & $\begin{array}{l}\text { Parasitic on } \\
\text { Arachis } \\
\text { hypogaea }\end{array}$ \\
\hline N. gossypiicola ${ }^{3}$ & $\begin{array}{l}\text { Pycnidial } 100-250 \mu \mathrm{m} \text { in diam, } \\
\text { globose to subglobose, solitary or } \\
\text { confluent, without or with one non- } \\
\text { papillate ostiole, honey, later } \\
\text { olivaceous to black Walls made up of } \\
3-10 \text { layers of cells. }\end{array}$ & $\begin{array}{l}\text { Globose to bottle- } \\
\text { shaped, } 5-8 \times 5-8 \mu \mathrm{m} \text {. }\end{array}$ & $\begin{array}{l}\text { Ellipsoidal with } \\
\text { several minute } \\
\text { guttules, aseptate, } \\
10-12.5 \times 2.5-3.5 \\
\mu \mathrm{m} .\end{array}$ & $\begin{array}{l}\text { globose to elongate, } \\
\text { usually in chains, } \\
\text { olivaceous with greenish } \\
\text { guttules, } 8-12 \mu \mathrm{m} \text { diam. }\end{array}$ & $\begin{array}{l}\text { On OA } 47-55 \mathrm{~mm} \text {, after } \\
7 \mathrm{~d} \text {, dull green to } \\
\text { olivaceous, reverse } \\
\text { olivaceous. } \mathrm{NaOH} \text { spot } \\
\text { test: negative. }\end{array}$ & $\begin{array}{l}\text { Parasitic on } \\
\text { Gossypium spp. }\end{array}$ \\
\hline N. infossa $a^{4}$ & $\begin{array}{l}\text { Pycnidial mostly solitary, subglobose } \\
\text { to elongated, } 190-250 \times 140-180 \mu \mathrm{m} \text {. } \\
\text { Ostioles mostly single } 40-75 \mu \mathrm{m} \text { diam. } \\
\text { Wall 5-9 layers, } 28.5-55 \mu \mathrm{m} \text { thick. }\end{array}$ & $\begin{array}{l}\text { Phialidic, hyaline, } \\
\text { simple, smooth, flask- } \\
\text { shaped, } 5.5-8 \times 5-5.5 \\
\mu \mathrm{m} .\end{array}$ & $\begin{array}{l}\text { Ovoid, thin-walled, } \\
\text { hyaline but } \\
\text { incidently brown, } \\
\text { aseptate, } 4.5-6 \times \\
2.5-3.5 \mu \mathrm{m} \text {, without } \\
\text { or with minute polar } \\
\text { guttules. }\end{array}$ & $\begin{array}{l}\text { Honey to cinnamon, } \\
\text { dictyosporous or } \\
\text { phragmosporous, solitary } \\
\text { or forming long chains, } \\
18-32 \times 11.5-17 \mu \mathrm{m}\end{array}$ & $\begin{array}{l}\text { On OA } 45-55 \mathrm{~mm} \text {, } \\
\text { olivaceous, reverse } \\
\text { gray. }\end{array}$ & $\begin{array}{l}\text { Parasitic on } \\
\text { Fraxinus } \\
\text { pennsylvanica }\end{array}$ \\
\hline N. macrospora ${ }^{5}$ & $\begin{array}{l}\text { Pycnidial pyriform, dark-brown, } 2-3 \\
\text { necks, } 100-300 \mu \mathrm{m} \text { in diam. Wall 3-5 } \\
\text { layers, } 15-25 \mu \mathrm{m}\end{array}$ & $\begin{array}{l}\text { Enteroblastic, phialidic, } \\
\text { globose to flask-shaped, } \\
\text { hyaline, } 5-10 \mu \mathrm{m} \text { diam. }\end{array}$ & $\begin{array}{l}\text { Cylindrical or } \\
\text { clavate, } 0(-2)- \\
\text { septate, } 10-15 \times 2.5- \\
3 \mu \mathrm{m} \text {, guttulate. }\end{array}$ & Absent & $\begin{array}{l}\text { On OA } 30 \mathrm{~mm} \text {, after } 7 \\
\text { d, olive brown, reverse } \\
\text { concolorous. }\end{array}$ & $\begin{array}{l}\text { Isolated from } \\
\text { human clinical } \\
\text { specimen. }\end{array}$ \\
\hline N. multilocularis ${ }^{6}$ & $\begin{array}{l}\text { Pycnidial globoe, stromatic, } \\
\text { uniloculate to multiloculate or } \\
\text { confluent with up to } 6 \text { long necks } \\
\text { diam. Wall } 38-80 \mu \mathrm{m} \text { thick, } 8-18 \text { cell } \\
\text { layers. }\end{array}$ & $\begin{array}{l}\text { Phialidic, flask-shaped } \\
\text { or polygonal, hyaline to } \\
\text { yellow-brown 11-17 } \times \\
9-18 \mu \mathrm{m} \text {. }\end{array}$ & $\begin{array}{l}\text { Unicellular, hyaline, } \\
\text { with a few minute } \\
\text { polar guttules, } \\
\text { cylindrical or } \\
\text { clavate } 9-20 \times 3-4 \\
\mu \mathrm{m} \text {. }\end{array}$ & $\begin{array}{l}10-16 \mu \mathrm{m} \text { in diam, } \\
\text { globose, subglobose to } \\
\text { polygonal, brown to dark- } \\
\text { brown, in chains, or in } \\
\text { large masses } 65-130 \times 22 \text { - } \\
45 \mu \mathrm{m} \text {. }\end{array}$ & $\begin{array}{l}\text { On OA } 40-45 \mathrm{~mm} \\
\text { diam, after } 7 \mathrm{~d} \text {, olive } \\
\text { brown, reverse olive } \\
\text { brown. } \mathrm{NaOH} \text { spot test: } \\
\text { negative. }\end{array}$ & $\begin{array}{l}\text { An endophyte of } \\
\text { Rhazya stricta. }\end{array}$ \\
\hline N. quercina ${ }^{7}$ & $\begin{array}{l}\text { Pycnidial solitary, globose, } 65-130 \times \\
95-200 \mu \mathrm{m} \text {, with single non-papillate } \\
\text { ostiole. Wall } 8.5-14.5 \mu \mathrm{m} .\end{array}$ & $\begin{array}{l}\text { Phialidic, hyaline, } \\
\text { simple, smooth, } \\
\text { doliiform to } \\
\text { ampulliform, } 3.5-5 \times 3-4 \\
\mu \mathrm{m} .\end{array}$ & $\begin{array}{l}\text { Subglobose to oval } \\
\text { or obtuse, aseptate, } \\
5.5-7.5 \times 3-4 \mu \mathrm{m} \text {, } \\
\text { with } 0-2 \text { minute } \\
\text { guttules, hyaline but } \\
\text { brown at maturity. }\end{array}$ & NA & $\begin{array}{l}\text { On OA } 55-68 \mathrm{~mm} \\
\text { diam, after } 7 \mathrm{~d} \text {, greenish } \\
\text { olivaceous, reverse } \\
\text { concolourous. }\end{array}$ & $\begin{array}{l}\text { Parasitic on } \\
\text { Quercus sp. }\end{array}$ \\
\hline
\end{tabular}

${ }^{1}$ Chen et al. 2015, ${ }^{2}$ De Gruyter et al. 1993, ${ }^{3}$ De Gruyter 2002, ${ }^{4}$ Aveskamp et al. 2009, ${ }^{5}$ Crous et al. 2016, ${ }^{6}$ This study, ${ }^{7}$ Aveskamp et al. 2010. 


\section{Key to species of Nothophoma}

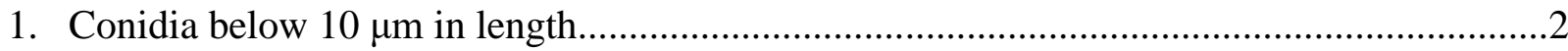

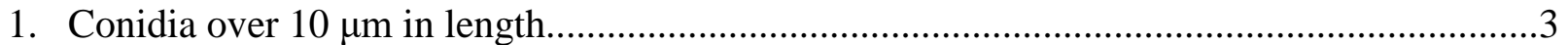

2. Parasitic on Anigozanthus spp.; pycnidia olivaceous buff, $70-130 \mu \mathrm{m}$ diam, turn black with age, $155-280 \times 140-230 \mu \mathrm{m}$, with 1-4(-6) long necks; conidia 3.5-5 × 1.5-2.5 $\mu \mathrm{m}$, aseptate, ellipsoidal.

N. anigozanthi

2. Parasitic on Arachis hypogaea; pycnidia citrine-honey then olivaceous to black, $80-200 \mu \mathrm{m}$ in diam, solitary or in rows, not confluent; conidia 3.2-5.2 $\times 1.8-2.4 \mu \mathrm{m}$, aseptate, oblong to ellipsoidal N. arachidis-hypogaeae

2. Parasitic on Fraxinus pennsylvanica; pycnidia mostly solitary, 190-250 × 140-180 $\mu$ m, with single ostiole; conidia 4.5-6 $\times$ 2.5-3.5 $\mu \mathrm{m}$, aseptate, ovoid, hyaline but incidentally brown N. infossa

3. Parasitic on Gossypium spp.; pycnidia 100-250 $\mu \mathrm{m}$ in diam, honey turn to olivaceous black with age, without or with non-papillate ostiole; conidia 10-12.5 $\times 2.5-3.5 \mu \mathrm{m}$, aseptate, ellipsoidal.

N. gossypiicola

3. Isolated from human clinical specimen, pycnidia 100-300 $\mu \mathrm{m}$ in diam., dark-brown, with 23 necks; conidia $0(-2)$-septate, $10-15 \times 2.5-3 \mu \mathrm{m}$, cylindrical or clavate N. macrospora

3. Endophyte of Rhazya stricta; pycnidia 175-1500 $\mu \mathrm{m}$ diam, black, with 1-6 necks; conidia 9$20 \times 3-4 \mu \mathrm{m}$, aseptate, cylindrical or clavate N. multilocularis

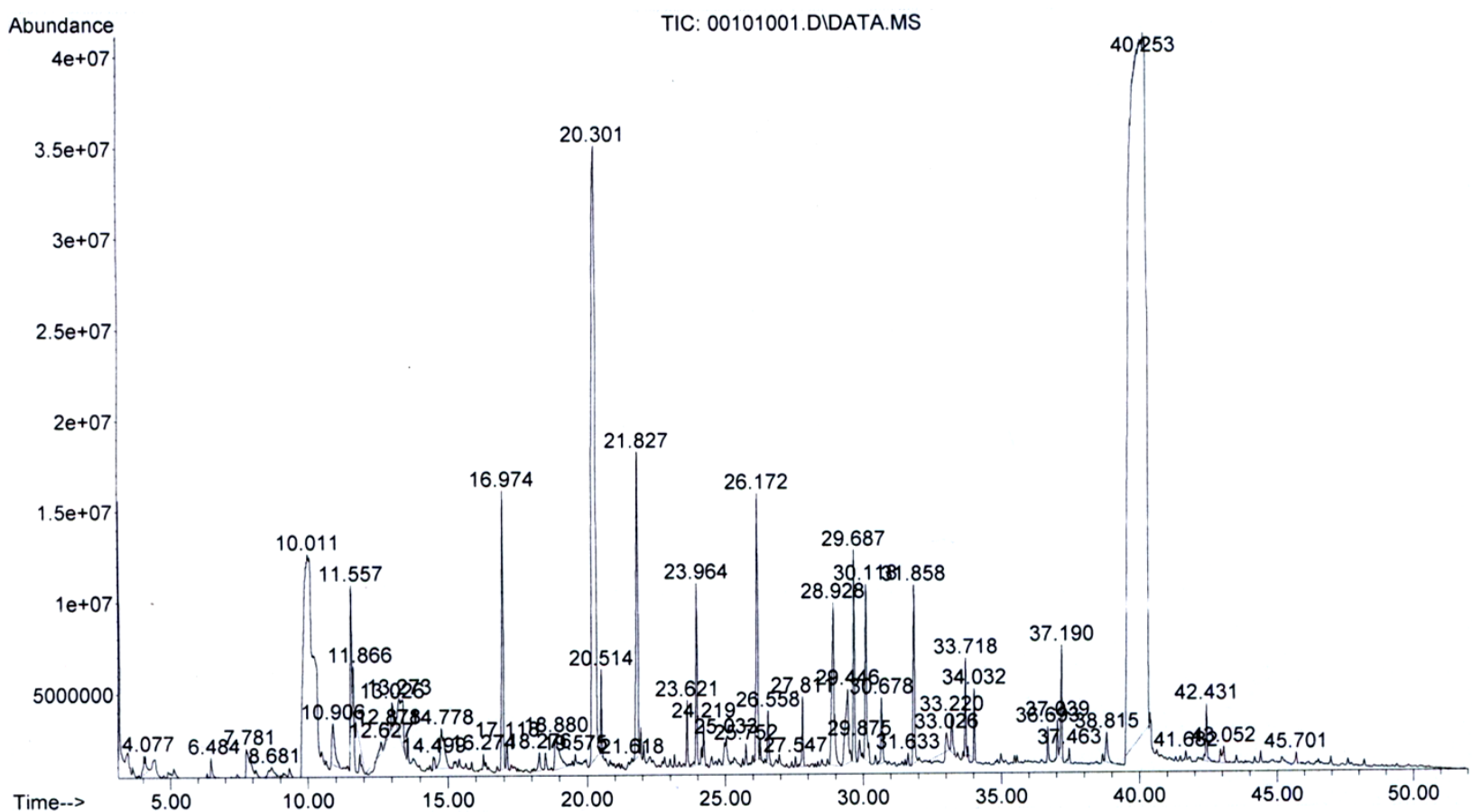

Fig. 2 - GC-MS chromatogram of the active fraction of the ethyl acetate of Nothophoma multilocularis.

communis and leaves of other plants and showed antibacterial effect (Sasty \& Rao 1995, Wei \& Wang 2006, Ruan et al. 2006, Sani \& Pateh 2009). Phthalates were reported to have antimicrobial and other pharamacological activities. Bis (ethyl hexyl) phthalate reported from Streptomyces bangladeshiensis showed antimicrobial activity against gram positive bacteria and some pathogenic fungi (Al-Bari et al. 2006). Phathalates showed anti-inflammatory (24) and anticancer activity (Nguyen et al. 2007, 
Mavar et al. 2008). The essential oil of Leea indica (Burm. F) Merr flowers showed phthalic acid esters (95.6\%) as major constituents and had good antibacterial and antifungal activity (Srinivasan et al. 2009).

Table 4 Major natural products compounds identified in the ethyl acetate extract from the culture filtrate of $N$. multilocularis by GC-MS:

\begin{tabular}{|c|c|c|c|c|c|c|}
\hline Peak & R- & & Molecular & Molecular & Area & \\
\hline No. & Time & Name of the compound & formula & weight & $\%$ & Activity \\
\hline 5 & 10.01 & Maltol & $\mathrm{C}_{6} \mathrm{H}_{6} \mathrm{O}_{3}$ & 126.11 & 9.45 & Antifungal \\
\hline 16 & 16.97 & 1-Tetradecene & $\mathrm{C}_{14} \mathrm{H}_{28}$ & 196.37 & 2.07 & Antimicrobial \\
\hline 21 & 20.3 & 2-Allyl-3,4-dimethoxybenzaldehyde & $\mathrm{C}_{11} \mathrm{H}_{12} \mathrm{O}_{3}$ & 192.21 & 10.26 & New compound \\
\hline 24 & 21.82 & Cetene & $\begin{array}{l}\mathrm{C}_{16} \mathrm{H}_{32} \\
\mathrm{C}_{14} \mathrm{H}_{21}\end{array}$ & 224.43 & 2.73 & Antioxidants \\
\hline 26 & 23.96 & Phenol, 2,4-di-t-butyl-6-nitrophenol & $\mathrm{NO}_{3}$ & 251.32 & 1.07 & Antimicrobial, anticancer \\
\hline 30 & 26.17 & E-15-Heptadecenal & $\mathrm{C}_{17} \mathrm{H}_{32} \mathrm{O}$ & 252.44 & 2.06 & Antimicrobial \\
\hline 34 & 28.92 & $\begin{array}{l}\text { 2,5-Cyclohexadien-1-one,2,6-bis } \\
\text { (1,1-dimethylethyl)-4-methylene- }\end{array}$ & $\mathrm{C}_{15} \mathrm{H}_{22} \mathrm{O}$ & 218.33 & 1.88 & \\
\hline 35 & 29.44 & Cyclo (L-Leucyl-L-Prolyl) & $\begin{array}{l}\mathrm{C}_{11} \mathrm{H}_{18} \\
\mathrm{~N}_{2} \mathrm{O}_{2}\end{array}$ & 210.27 & 1.17 & $\begin{array}{l}\text { Antifungal and } \\
\text { anti-aflatoxins production }\end{array}$ \\
\hline 38 & 30.12 & 1-Octadecene & $\mathrm{C}_{18} \mathrm{H}_{36}$ & 252.48 & 1.36 & \\
\hline 51 & 40.25 & Di-n-octyl phthalate & $\mathrm{C}_{24} \mathrm{H}_{38} \mathrm{O}_{4}$ & 390.56 & 53.98 & $\begin{array}{l}\text { Antimicrobial, antioxidant } \\
\text { Plasticizer, cosmetics }\end{array}$ \\
\hline
\end{tabular}

2-Allyl-3, 4-dimethoxybenzaldehyde (10.26\%) is the second major compound in the active fraction of the crude. This compound seems to be a new compound and we will do more analytical work on it. Maltol $(9.45 \%)$ is the third major compound in the crude extract. Maltol is a naturally occurring organic compound that is used primarily as a flavor enhancer and has excellent anti-oxidative activity (Hong et al. 1992). Maltol was isolated from the bark of larch tree, pine needles and found also in roasted malt. However, maltol has rarely been described as a microbial metabolite (Cunningham \& Pickard 1985).

\section{Chemical structure of the 10 major compounds}

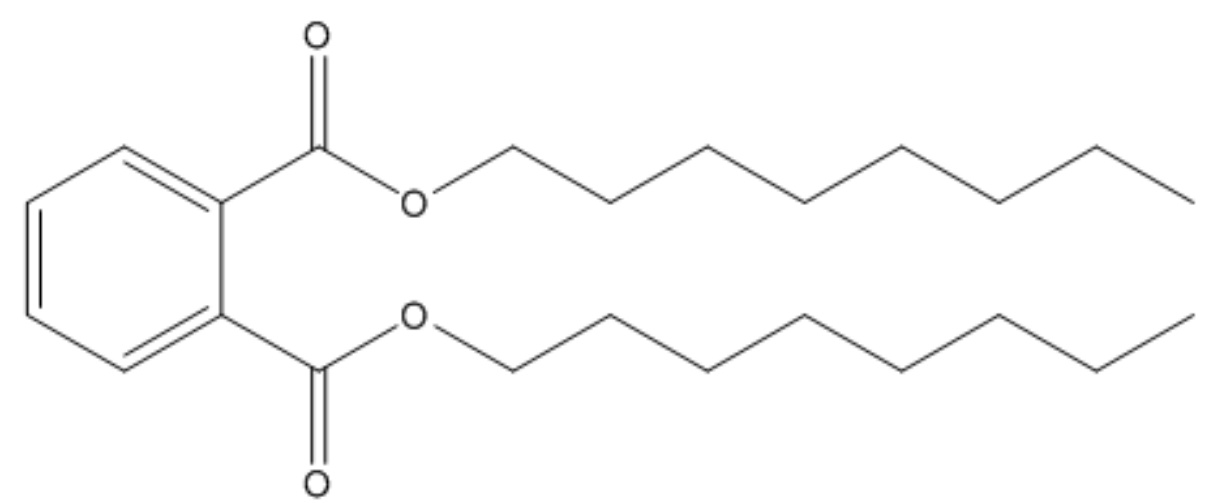

Di-n-octyl phthalate 
<smiles>Cc1occc(=O)c1O</smiles>

Maltol<smiles>C=CCc1c(C=O)ccc(OC)c1OC</smiles>

2-Allyl-3,4-dimethoxybenzaldehyde<smiles>C=CCCCCCCCCCCCC</smiles><smiles>C=CCCCCCCCCCCCCCC</smiles><smiles>CC(C)(C)c1cc([N+](=O)[O-])c(O)c(C(C)(C)C)c1</smiles>

2,4-di-t-butyl-6-nitrophenol

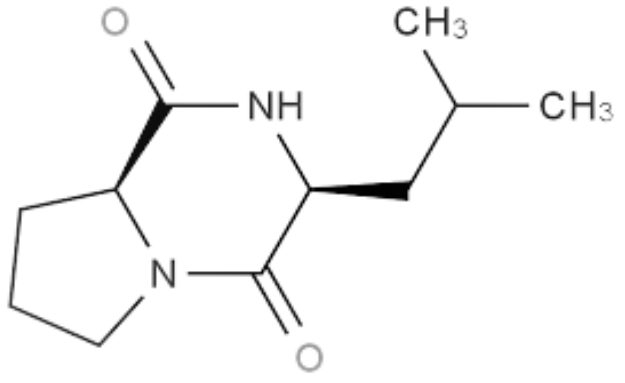

Cyclo (L-Leucyl-L-Propyl)

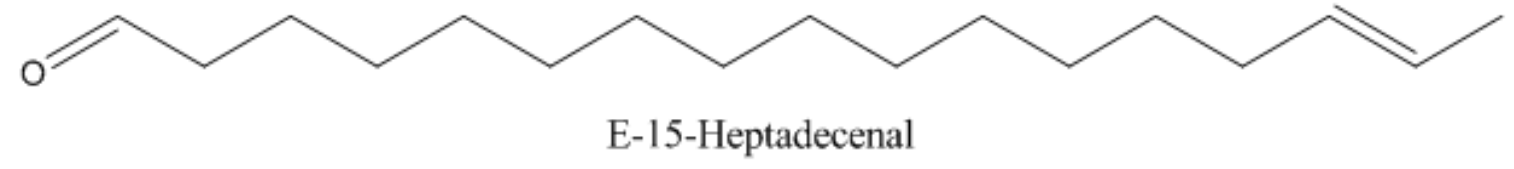




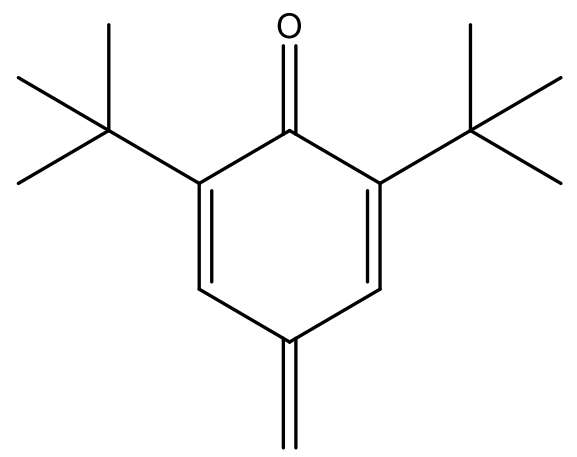

2,5-cyclohexadien-1-one, 2,6-bis(1,1-dimethylethyl)-4-methylene-

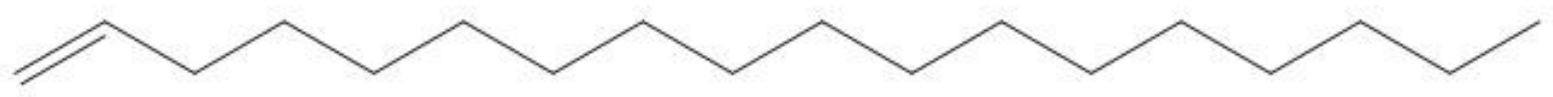

1-Octadecene

\section{Acknowledgements}

This project was supported by King Abdulaziz City of Science and Technology (KACST), Saudi Arabia (Project No. AT-35-155).

\section{References}

Abdel-Wahab MA, Bahkali AH, Jones EBG, Elgorban AM et al. 2016 - Two new species of Kallichroma (Bionecteriaceae, Hypocreales) from Saudi Arabian mangroves. Phytotaxa 260, 66-74.

Adam SEI. 1998 - Toxicity of Rhazya stricta to sheep. Veterinary and Human Toxicology 40, 6869.

Al-Bari MAA, Sayeed MA, Rahman MS, Mossadik MA. 2006 - Characterization and antimicrobial activities of a phthalic acid derivative produced by Streptomyces bangladeshiensis- A novel species in Bangladesh. Research Journal of Medicine and Medical Sciences 1, 77-81.

Ali L, Khan AL, Hussain J, Al-Harrasi A et al. 2016 - Sorokiniol: a new enzymes inhibitory metabolite from fungal endophyte Bipolaris sorokiniana LK12. BMC Microbiology 16, 1-9.

Andersen WK, Omar AA, Christensen SB. 1987 - Isorhamnetin-2,6)3dirhamnopyranosylgalactoside)-7-rhamnoside and 3-6)-rhamnopyranosyl galatoside)-7rhamnoside from Rhazya stricta. Phytochemistry 26, 291-294.

Atta-ur-Rahman, Khanum S. 1985 - 2-Methoxy-1,2-dihydrorhazimine, an alkaloid from the leaves of Rhazya stricta. Phytochemistry 24, 1625-1626.

Atta-ur-Rahman, Khanum S. 1987 - Isolation and structural studies on the alkaloids of Rhazya stricta. Heterocycles 26, 405-412.

Atta-ur-Rahman, Malik S. 1985 - Vincadine from the legumes of Rhazya stricta. Journal of Natural Products 48, 153-154.

Atta-ur-Rahman, Malik S. 1987 - Strictanol and strictanine - Two new indole alkaloids from the fruits of Rhazya stricta. Phytochemistry 26, 589-591.

Atta-ur-Rahman, Zaman K, Khanum S, Muzaffar A et al. 1996 - Strictigine - a novel 4vinylquinoline alkaloid from Rhazya stricta. Natural Products Letter 8: 55-66.

Aveskamp MM, Verkley GJM, De Gruyter J, Murace MA et al. 2009 - DNA phylogeny reveals 
polyphyly of Phoma section Peyronellaea and multiple taxonomic novelties. Mycologia 101, 363-382.

Aveskamp MM, De Gruyter J, Woudenberg JHC, Verkley GJM et al. 2010 - Highlights of the Didymellaceae: a polyphasic approach to characterize Phoma and related pleosporalean genera. Studies in Mycology 65, 1-60.

Baeshen NA, Elkady AI, Yaghmoor SS, Al Ashmaoi HM et al. 2014 - Evaluation of the cytotoxicity and genotoxicity of alkaloid-rich and alkaloid-free aqueous extracts of Rhazya stricta leaves. Bothalia Journal 44, 358-371.

Baeshen MN, Khan R, Bora RS, Baeshen NA. 2015 - Therapeutic Potential of the Folkloric Medicinal Plant Rhazya stricta. Biological Systems Open Access 5, 1-5.

Bai J, Wang X, Shi Y, Duan C. 2016 - Occurrence and identification of Nothophoma quercina causing brown spot of jujube in China. Canadian Journal of Plant Pathology 38, 527-532.

Boulos L. 1995 - Flora of Egypt. Checklist, pp. 283. Al Hadra Publishing, Cairo, Egypt.

Chen Q, Jiang JR, Zhang GZ, Cai L et al. 2015 - Resolving the Phoma enigma. Studies in Mycology 82, 137-217.

Crous PW, Wingfield MJ, Richardson DM, Le Roux JJ et al. 2016 - Fungal Planet description sheets: 400-468. Persoonia 36, 316-458.

Cunninghajm E, Pickard MA. 1985 - Maltol, a metabolite of Scytalidium uredinicola which inhibits spore germination of Endocronartium harknessii, the western gall rust. Canadian Journal of Microbiology 31, 1051-1055.

De Gruyter J. 2002 - Contributions towards a monograph of Phoma (Coelomycetes). IX section Macrospora. Persoonia 18, 85-102.

De Gruyter J, Noordeloos ME, Boerema GH. 1993 - Contributions towards a monograph of Phoma (Coelomycetes) - I. 2. Section Phoma: additional taxa with very small conidia and taxa with conidia up to $7 \mu \mathrm{m}$ long. Persoonia 15, 369-400.

De Silva DD; Rapior S, Sudarman E, Stadler M et al. 2013 - Bioactive metabolites from macrofungi: ethnopharmacology, biological activities and chemistry. Fungal Diversity 62, 1-40.

Duc N, Dung N, Lyun HL, Hyang-Bok L et al. 2007 - Isolation of dioctyl phthalate with high depigmenting effect from Chinese herb Nigella glandulifera Freyn. Journal of Biotechnology 131, S43.

Degenkolb T, Vilcinskas A. 2016 - Metabolites from nematophagous fungi and nematicidal natural products from fungi as alternatives for biological control. Part II: metabolites from nematophagous basidiomycetes and non-nematophagous fungi. Applied Microbiology and Biotechnology 100, 3813-3824.

El-Ghonemy AA. 1993 - Encyclopedia of medicinal plants of the United Emirates, University of UAE, Al Ain.

Felsenstein J. 1981 - Evolutionary trees from DNA sequences: a maximum likelihood approach. Journal of Molecular Evolution 17, 368-376.

Garcia A, Rhoden SA, Rubin-Filho CJ, Nakamura CV et al. 2012 - Diversity of foliar endophytic fungi from the medicinal plant Sapindus saponaria L. and their localization by scanning electron microscopy. Biological Research 45, 139-148.

Gilani SA, Kikuchi A, Shinwari ZK, Khattak ZI et al. 2007 - Phytochemical, pharmacological and ethnobotanical studies of Rhazya stricta Decne. Phytotherapy Research 21, 301-307.

Guo LD, Hyde KD, Liew ECY. 2000 - Identification of endophytic fungi from Livistona chinensis based on morphology and rDNA sequences, New Phytologist 147, 617-630. 
Guo LD, Hyde KD, Liew ECY. 2001 - Detection and taxonomic placement of endophytic fungi within frond tissues of Livistona chinensis based on rDNA sequences. Molecular Phylogenetics and Evolution 20, 1-13.

Hong YL, Pan HZ, Scott MD, Meshnick SR. 1992 - Activated oxygen generation by a primaquine metabolite: Inhibition by antioxidants derived from Chinese herbal remedies. Free Radical Biology and Medicine 12, 213-218.

Huelsenbeck JP, Ronquist F. 2001 - MRBAYES: Bayesian inference of phylogeny. Bioinformatics 17, 754-755.

Hyde KD, Soytong K. 2008 - The fungal endophyte dilemma. Fungal Diversity 33, 163-173.

Khan AL, Ali L, Hussain J, Rizvi TS et al. 2015 - Enzyme inhibitory radicinol derivative from endophytic fungus Bipolaris sorokiniana LK12, associated with Rhazya stricta. Molecules 20, 12198-12208.

Khan AL, Gilani SA, Waqas M, Al-Hosni K et al. 2017 - Endophytes from medicinal plants and their potential for producing indole acetic acid, improving seed germination and mitigating oxidative stress. Journal of Zhejiang University-Science B 18, 125-137.

Kharwar RN, Strobel GA, Ezra D. 2008 - The endophytic fungal complex of Catharanthus roseus (L.). Current Science 95, 228-233.

Kohn MC, Parham F, Masten SA. 2000 - Human exposure estimates for phthalates. Environmental Health Perspect 108, A440-442.

Lacap DC, Hyde KD, Liew ECY 2003 - An evaluation of the fungal 'morphotype' concept based on ribosomal DNA sequences. Fungal Diversity 12, 53-66.

Li H, Qing C, Zhang Y, Zhao Z. 2005 - Screening for endophytic fungi with antitumor and antifungal activities from Chinese medicinal plants. World Journal of Microbiology and Biotechnology 21, 1515-1519.

Liu X, Dou G, Ma Y. 2016 - Potential of endophytes from medicinal plants for biocontrol and plant growth promotion. Journal of General Plant Pathology 82, 165-173.

Maharachchikumbura SSN, Hyde KD, Jones EBG, McKenzie EHC et al. 2016 - Families of Sordariomycetes. Fungal Diversity 79, 1-317.

Mavar MH, Haddad M, Pieters L, Bacceli C et al. 2008 - Anti-inflammatory compounds from leaves and root bark of Alchornea cordifolia (Schum and Thonn.) Muell. Argentina Journal of Ethnopharmacology 115, 25-29.

Nalini MS, Sunayana N, Prakash HS. 2014 - Endophytic fungal diversity in medicinal plants of Western Ghats, India. International Journal of Biodiversity 2014, 1-9.

Nath A, Chattopadhyay A, Joshi SR. 2015 - Biological activity of endophytic fungi of Rauwolfia serpentine Benth: an ethnomedicinal plant used in folk medicines in northeast India. PNAS 85, 233-240.

Nehdi IA, Sbihi H, Al Resayes SI. 2014 - Rhazya stricta Decne seed oil as an alternative nonconventional feedstock for biodiesel production. Energy Conversion and Management 81, 400-406.

Nguyen DT, Nyugen DH, Lyun HL, Lee HB et al. 2007 - Inhibition of melanogenesis by diocyl phthalate isolated from Nigella glandulifera Freyn. Journal of Microbiology and Biotechnology 17, 1585-1590.

Nisa H, Kamili AN, Nawchoo IA, Shafi S et al. 2015 - Fungal endophytes as prolific source of phytochemicals and other bioactive natural products: A review. Microbial Pathogenesis 82: $50-59$. 
Nylander JAA. 2004 - MrModeltest v2. Program distributed by the author. Evolutionary Biology Center, Uppsala University, Uppsala.

Perrière G, Gouy M. 1996 - WWW-query: an on-line retrieval system for biological sequence banks. Biochimie 78, 364-369.

Posada D, Crandall KA. 1998 - MODELTEST: testing the model of DNA substitution. Bioinformatics 14, 817-818.

Ronquist F, Huelsenbeck JP. 2003 - MRBAYES 3: Bayesian phylogenetic inference under mixed models. Bioinformatics 19, 1572-1574.

Ruan HL, Zhang Y, Zhang YH, Pi HF et al. 2006 - Studies on constituents from roots of Euphorbia hylonoma. Zhongguo Zhong Yao Za Zhi 31, 742-744.

Sani UM, Pateh UU. 2009 - Isolation of 1, 2-benzenedicarboxylic acid bis(2-ethylhexyl) ester from methanol extract of the variety minor seeds of Ricinus communis Linn. (Euphorbiaceae). Nigerian Journal of Pharmaceutical Sciences 8, 2.

Sastry VMVS, Rao GRK. 1995 - Dioctyl phthalate and antibacterial compound from the marine brown alga Sargassum wightii. Journal of Applied Physiology 7, 185-186.

Srinivasan GV, Sharanappa P, Leela NK, Sadashiva CT et al. 2009 - Chemical composition and antimicrobial activity of Leea indica (Burm. F) Merr flowers. Natural Product Radiance 8, 5.

Swofford DL. 2002 - PAUP* 4.0: phylogenetic analysis using parsimony (*and other methods). Sinauer, Sunderland, MA.

Sultana N, Choudhary MI, Ali S, Anjum S et al. 2005 - 5,7-Dihydroxy-6,2'-dimethoxyisoflavone. Acta Cryst E61, 1812-1814.

Täckholm V. 1974 - Students' Flora of Egypt, p. 888. Cairo University Press, Cairo, Egypt.

Tao G, Liu ZY, Hyde KD, Liu XZ et al. 2008 - Whole rDNA analysis reveals novel and endophytic fungi in Bletilla ochracea (Orchidaceae). Fungal Diversity 33, 101-122.

Thompson JD, Gibson TJ, Plewniak F, Jeanmougin F et al. 1997 - The ClustalX windows interface: flexible strategies for multiple sequence alignment aided by quality analysis tools. Nucleic Acids Research 25, 4876-4882.

Tibpromma S, Hyde KD, Jeewon R, Maharachchikumbura SSN et al. 2017 - Fungal diversity notes 491-602: taxonomic and phylogenetic contributions to fungal taxa. Fungal Diversity 83, 1261.

Wang Y, Guo LD, Hyde KD. 2005 - Taxonomic placement of sterile morphotypes of endophytic fungi from Pinus tabulaeformis (Pinaceae) in northeast China based on rDNA sequences. Fungal Diversity 20, 235-260.

Verma VC, Gond SK, Kumar A, Kharwar RN et al. 2007 - The endophytic mycoflora of bark, leaf, and stem tissues of Azadirachta indica A. Juss (Neem) from Varanasi (India). Microbial Ecology 54, 119-125.

Vilgalys R, Hester M. 1990 - Rapid genetic identification and mapping of enzymatically amplified ribosomal DNA from several Cryptococcus species. Journal of Bacteriology 172, 4238-4246.

Wei YX, Wang JX. 2006 - Studies on the chemical constituents of hypogeal part from Limonium bicolour. Zhong Yao Cai 29, 1182-1184. 